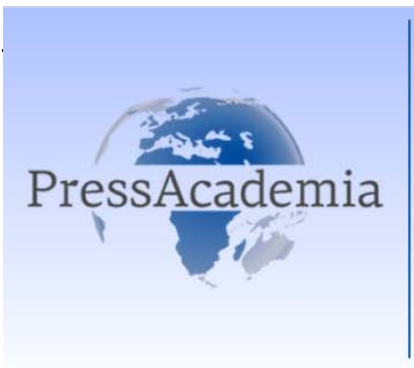

Press Academia Procedía

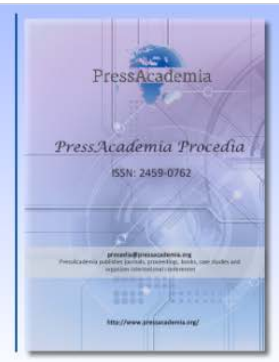

Global Business Research Congress (GBRC), May 26-27, 2016, Istanbul, Turkey.

\title{
THE EFFECT OF CONSUMER INVOLVEMENT ON BRAND LOYALTY
}

\section{DOI: 10.17261/Pressacademia.2016118636}

\author{
Volkan Ozbek ${ }^{1}$ Aycan Kulahli \\ ${ }^{1}$ Balıkesir Üniversitesi. vozbek@balikesir.edu.tr \\ ²Balıkesir Üniversitesi. aycan.kulahli@hotmail.com
}

\begin{abstract}
The main aim of this study is to reveal the effect of consumers' product involvement levels on their brand loyalty in terms of smart phones. In order to achieve this goal, a research was implemented by using face to face survey method on 665 Balıkesir University Burhaniye School of Applied Science students who are determined with convenience sampling method. The reason of using this sample is the anticipation of that university students' consciousness and involvement levels about smart phones might be higher than other populations. In order to determine consumer involvement level, Consumer Involvement Profiles (CIP), which is developed by Kapferer and Laurent (1985) and one of commonly used scales in consumer involvement researches, was used. This scale is composed of five dimensions including interest (perceived importance), hedonic value (pleasure), symbolic value (sign), risk importance, and risk probability. As for brand loyalty, a 6 -item scale that developed by Zeithaml, Berry, and Parasuraman (1996) as five items and one dimension, and then, adapted by Lam, Shankar, Erramilli, and Murthy (2004) as two dimensions (repurchase/ patronage and recommendation) by adding one item to repurchase/ patronage dimension, was used. The research results demonstrate that symbolic value, risk probability, and hedonic value dimensions of consumer involvement have effects on repurchase/ patronage dimension of brand loyalty. In addition, the results support that interest, symbolic value, risk probability, and hedonic value dimensions of consumer involvement have effects on recommendation dimension of brand loyalty. With reference to these results, the findings were interpreted and the study was concluded with suggestions to researchers and managers.
\end{abstract}

Keywords: Consumer Involvement, brand loyalty, consumer involvement profiles, smart phone.

JEL Codes: M30, M31.

\section{TÜKETICi iLGILENIMININ MARKA SADAKATi ÜZERINDEKI ETKISI}

\section{ÖZET}

Bu araştırmanın temel amacı, tüketicilerin ürün ilgilenim düzeylerinin marka sadakati üzerindeki etkisini akıllı telefon ürünü özelinde ortaya koymaktır. Bu amaca ulaşmak için, Balıkesir Üniversitesi Burhaniye Uygulamalı Bilimler Yüksekokulu öğrencileri arasından kolayda örnekleme yöntemi ile araştırmaya dâhil edilen 665 öğrenci üzerinde yüz yüze anket yöntemiyle bir uygulama gerçekleştirilmiştir. Araştırmada bu kitlenin kullanılmasının nedeni, üniversite öğrencilerinin akıllı telefon ürününe yönelik bilinç ve ilgilenim düzeyinin diğer kitlelerden daha yüksek olacağı beklentisidir. Araştırmada tüketici ilgilenim düzeylerinin belirlenmesinde Kapferer ve Laurent tarafından (1985) geliştirilen ve tüketici ilgilenimi araştırmalarında yaygın olarak kullanılan ölçeklerden biri olan Tüketici ỉlgilenim Profili (Consumer Involvement Profiles, CIP) kullanılmıştır. Bu ölçek, ilgi, hedonik değer, sembolik değer, risk önemi ve hata olasılığı olmak üzere beş boyuttan oluşmaktadır. Marka sadakatini ölçmek için ise, Zeithaml, Berry ve Parasuraman (1996) tarafından geliştirilen ve beş ifadeden oluşan tek boyutlu ölçeğin Lam, Shankar, Erramilli ve Murthy (2004) tarafından adapte edilmiş iki boyutlu (tekrar satın alma/ müşterisi olma 2 ifade ve tavsiye etme 3 ifade) versiyonunun tekrar satın alma/ müşterisi olma boyutuna bir soru eklenerek oluşturulan 6 soruluk ölçek kullanılmıştır. Araştırma sonuçları, tüketici ilgilenim boyutlarından sembolik değer, hata olasılığı ve hedonik değerin sadakatin tekrar satın alma/ müşterisi olma boyutu üzerinde etkili olduğunu göstermektedir. Buna ek olarak, ilgi, sembolik değer, hata olasılığı ve hedonik değerin sadakatin tavsiye etme boyutu üzerinde etkili olduğunu da araştırma bulguları desteklemektedir. Bu bulgulardan hareketle araştırma sonuçları yorumlanmış; yöneticilere ve akademisyenlere önerilerde bulunularak araştırma tamamlanmıştır.

Anahtar Kelimeler: Tüketici ilgilenimi, marka sadakati, tüketici ilgilenim profili, akıllı telefon. JEL Kodları: M30, M31. 


\section{GiRiş}

Teknolojinin ve pazarlama anlayışının gelişmesiyle birlikte, firmaların ürün ve hizmetlerine erişmek daha kolay hale gelmiş ve müşteriler için seçenekler artmıştır. Öte yandan, sayısız ürün seçeneğine sahip olan müşteriyi memnun edip uzun süre aynı markaya sadık kalmasını sağlamak da firmalar açısından zorlaşmıştır. Oysa firmalar açısından sadık bir müşteri portföyü oluşturmak, günümüzün rekabetçi iş dünyasında var olabilmek açısından elzemdir. Marka sadakatini artırmak için tüketicilerin ürüne ya da markaya yönelik ilgilenim düzeylerini bilmek ve buna yönelik stratejiler geliştirerek önlem almak yararlı olacaktır. Nitekim Warrington ve Shim (2000), yüksek ilgilenim düzeyine sahip müşterilerin, memnun olduklarında markaya veya firmaya yönelik sadakat duygusu geliştirdiklerini ve bu müşterilerin işletme açısından önemli bir pazar bölümü oluşturduğunu belirtmektedir (Dölarslan, 2015, s.27). Bu bağlamda ilgilenim, hem müşteri memnuniyetini, hem de marka sadakatini etkilemesi bakımından önemli bir kavramdır. Kapferer ve Laurent'e göre (1985) ilgilenim beş boyuttan oluşmaktadır. Bu boyutlar ilgi, hedonik değer, sembolik değer, risk önemi ve hata olasılığı olarak adlandırılmıştır. Bu boyutların her birinin marka sadakati üzerindeki etkisini belirlemek, farklı özellikteki tüketiciler için farklı pazarlama stratejileri geliştirebilmek bakımından önemlidir. Ancak bu etkiyi inceleyebilmek için tüketicilere soyut kavramlar üzerinden değil, somut bir ürün üzerinden yaklaşmak gerekmektedir. Örneğin, tüketicilerin neye ilgi duyacağı, neyi sembolik ya da hedonik olarak algılayacağı, hangi ürünün satın alımında hata olasılı̆̆ı algılayacağı gibi sorular ancak somut bir ürün üzerinden araştırma yürütüldüğünde cevap bulabilecektir. Bu noktadan hareketle, bu araştırmanın amacı tüketici ilgileniminin marka sadakati üzerindeki olası etkisini akıllı telefon ürünü özelinde ortaya koymaktır. Bu amaca ulaşmak için öncelikle bir literatür çalışması yapılmıştır. Ardından, akıllı telefon ürünü özelinde üniversite öğrencileri üzerinde bir çalışma yürütülmüştür. Son olarak araştırma bulguları değerlendirilmiş; firmalara önerilerde bulunularak çalışma tamamlanmıştır.

\section{LITERATÜR ARAŞTIRMASI}

Bu bölümde marka sadakati ve tüketici ilgilenimi değişkenlerine yönelik yürütülen literatür araştırması sunulmaktadır.

\subsection{Marka Sadakati}

Günümüzün yoğun tüketim toplumunda, çok sayıda ürün arasından seçim yapmak durumunda kalan tüketici, daha seçici davranmakta ve markalaşmış ürünler tercih etmektedir (Öztürk, 2006, s.66). İyi bir marka oluşturmak ve rekabetin yoğun olduğu tüketici pazarlarında başarılı olmak firmalar açısından da büyük önem taşımaktadır (Çiftyıldız ve Sütütemiz, 2007, s.38). Marka kavramının giderek önem kazanması, onunla ilişkili birçok kavramın da incelenmesine neden olmuştur. Bu kavramların başında da marka sadakati gelmektedir (Gounaris ve Stathakopoulos, 2004, s.283). Oliver'a göre (1999) marka sadakati, markayı değiştirme davranışına yol açma potansiyeline sahip dış etkenlere ve pazarlama çabalarına rağmen, marka veya hizmeti tekrar satın alma veya tekrar müşterisi olması vaadi olarak tanımlamıştır (Oliver, 1999, s.34). Zeithaml, Berry ve Parasuraman (1996) ise sadakat kavramını, tüketicinin gelecekte ürün veya hizmeti tekrar satın alması, ürün ya da hizmetin sürekli müşterisi olması, yani sürekli olarak aynı mal ve hizmeti ya da firmayı tercih etmesi ve olumlu tavsiyelerde bulunması şeklinde tanımlamışlardır. Dick ve Basu (1994) çeşitli şekilleri olmakla birlikte sadakati, gelecekte ürün veya hizmetin tekrar satın alınması veya var olan ilişkinin sürdürülmesi olarak tanımlamaktadır (Flint, Blocker ve Boutin, 2011, s.222). Bu bağlamda marka sadakati, tüketicilerin daha önceden satın alıp denedikleri bir markayı satın almayı sürdürme eğilimi ya da tüketicinin belirli bir süre içerisinde bir ürün sınıfı içinde yer alan bir ya da daha çok markaya karşı takındığı olumlu tutum ve davranışsal tepki şeklinde tanımlanabilir (Yılmaz, 2005, s. 260).

Marka sadakati konusu günümüzde oldukça üzerinde durulan ve araştırılan bir konudur. Çünkü sadakat firmalar açısından kalıcı ve uzun vadeli başarının anahtarlarından birisi olarak görülmektedir (Eren ve Erge, 2012, s.4457). İşletmeler için artık önemli olan, ne kadar çok sayıda yeni müşteri kazandıkları değil, mevcut müşterilerden ne kadarını işletmeleri ile uzun dönemli bir ilişki içerisinde tutabildikleridir (Coşkun, 2007, s.1). Diğer bir deyişle, yoğun rekabet ortamında işletmelerin markalarını ayakta tutabilmek için sadık müşterilere sahip olmaları gerekmektedir. İşletmelerin mevcut müşterilerini ellerinde tutmalarının, yeni müşteriler kazanmalarından daha az maliyetli, dolayısıyla işletmeler için daha karlı olduğu düşünüldüğünde marka 
sadakatinin işletmeler açısından önemi ortaya çıkmaktadır (Tokmak, 2014, s.1). Marka sadakatinin sağlanması işletmeye beraberinde pek çok avantaj getirir. Aeker'e göre (1991) bu avantajlar, azalan pazarlama harcamaları, perakende noktalarda daha baskın olma, yeni müşterileri çekme ve rakip faaliyetler karşısında vakit kazanma olarak sıralanmıştır (Fırat ve Azmak, s.255). Marka sadakati, yarattığı bu önemli ve stratejik sonuçlarından dolayı firmaların pazarlama faaliyetlerinin temelini ve stratejik pazarlama planının amacını oluşturmaktadır (Devrani, 2009, s.408).

Pazarlama literatüründe marka sadakati üzerine yürütülen çalışmalar, genel olarak sadakati etkilediği düşünülen değişkenlere odaklanmıştır. Bu değişkenler arasında memnuniyet, tüketici güveni, algılanan risk, algılanan değer, marka imajı, motivasyon ve ilgilenim gibi kavramlar başı çekmektedir. Bu kavramların sadakat üzerindeki etkilerinin ortaya konması ile firmaların arzu ettiği sadık müşterilerin elde edilmesi kolaylaşacaktır.

\subsection{Tüketici ilgilenimi}

İlgilenim kavramı son yıllarda giderek artan bir şekilde sosyal psikoloji ve tüketici davranışı alanlarında yaygın olarak kullanılan bir kavramdır. Çünkü tüketicilerin ilgilenim düzeylerinin bilinmesi tüketici davranışlarının tahmini ve incelenmesinde son derece önemlidir (Prebensen, Woo, Chen ve Uysal, 2013, s.256). İlk kez 1947 yılında psikoloji alanında Sherif ve Sargent tarafından ortaya atılan ilgilenim kavramı, pazarlama alanında Krugman'ın televizyon reklamlarının öğrenilme biçimleri üzerine yapmış olduğu bir araştırma ile yaygınlık kazanmıştır (Çakır, 2007, s.164). Krugman'a (1965) göre ilgilenim, seyircinin bir dakika içerisinde kendi yaşamı ile uyarıc arasında bilinçli olarak kurduğu köprü, ilişki, bağlantı ya da kişisel referans sayısı olarak tanımlanmıştır (Kandemir vd., 2013, s.22). Ancak bundan sonra yapılan tanımlarda ilgilenim kavramının farklı açılardan ele alındığı görülmektedir.

İlgilenim kavramıyla ilgili geliştirilen pek çok tanımda bu kavramın "kişisel ilgi" temelinde şekillendiği görülmüştür (Zaichkowsky, 1986, s.4-5). Bu bağlamda Day (1970), tüketici ilgisini nesneye olan genel ilgi düzeyi ya da nesnenin kişinin ego yapısına odaklanmış olması olarak tanımlarken; Martin (1998) bu olguyu "ürünün kişisel anlamı" ve "tüketici-ürün ilişkisi" olarak tanımlamaktadır (Çiftyıldız ve Sütütemiz, 2007, s.38). Bir başka tanıma göre ilgilenim, "genel anlamda, bireyin ihtiyaçları, kişisel değerleri ve ilgi alanlarına bağlı olarak herhangi bir obje/ürün ile bireyin algılanan ilişkisi" olarak tanımlanmıştır (Zaichkowsky, 1985, s.342). Diğer bir ifadeyle ilgilenim, "belirli bir durumda bir tüketicinin bir uyaran (ürün, mağaza, hizmet, reklam ve mesaj gibi) için hissettiği kişisel önem ve ilgi düzeyidir" (Odabaşı ve Barış, 2002, s.342).

İlgilenimin farklı biçimlerde tanımlanması birçok farklı ölçeğin ortaya çıkmasına yol açmıştır. Bunlardan en önemlileri Zaichkowsky'nin (1985) Kişisel ilgilenim Envanteri (Personal Involvement Inventory-PII) ve Kapferer ve Laurent'in (1985) Tüketici İlgilenim Profili'dir (Consumer Involvement Profiles-CIP). PII tek boyutlu iken CIP çok boyutlu bir ölçektir (Prayag and Ryan, 2012, s.344). Literatürde ilgilenimi tanımlamaya ve ölçmeye yönelik gerçekleştirilen çalışmalar bu kavramın çok boyutlu olduğunu göstermektedir (Kapferer ve Laurent, 1985; Bloch, 1986; Mittal, 1995). Bu nedenle literatürde CIP kullanılarak yapılan çalışmalara daha sık rastlanmaktadır. CIP'e göre tüketici ilgilenimi beş boyuttan oluşmaktadır. Bu boyutlar ilgi, hedonik değer, sembolik değer, risk önemi ve hata olasılığı olarak adlandırılmıştır.

CIP ölçeğinin ilk öncülü olan ürüne duyulan ilgi, ürünün kişi için önemini, anlamını ve ürüne yönelik kişisel ilgiyi ifade etmektedir. İlgilenimin hedonik değer boyutu, ürünün zevk verme ve duyguları uyarma olasılığı ile ilişkilidir. İlgilenimin üçüncü öncülü olan sembolik değer (işaret değeri), tüketicinin mal ya da hizmete yüklediği değer ile ilgilidir. İlgilenimin öncüllerinden dördüncüsü ürünün satın alınması ile ilişkilendirilen risktir. Risk önemi, yanlış ürün seçiminin doğuracağı olumsuz sonuçların algılanan önemini ifade eder. Son öncül olan hata olasılığı ise kötü bir ürün seçme riski ile ilişkilendirilmiştir (Kandemir vd., 2013, s.27). Kapferer ve Laurent'in geliştirdiği ölçekteki alt boyutlar Tablo 1'de özetlenmektedir. 
Tablo 1. Tüketici ilgileniminin Alt Boyutları

\begin{tabular}{|l|l|}
\hline İlgilenimin Alt Boyutları & Açıklama \\
\hline Algılanan önem/ilgi & $\begin{array}{l}\text { Tüketicinin belli bir ürün kategorisine karşı kişisel ilgisi, ürünün kişisel } \\
\text { anlamı ya da önemi. }\end{array}$ \\
\hline Hedonik Değer & Ürünün hazcı değeri, haz ve mutluluk sağlama yeteneği. \\
\hline Sembolik değer & Ürünün sembolik değeri, bireyi ifade etme yeteneği. \\
\hline Risk Önemi & Yanlış bir ürün seçiminin doğuracağı negatif sonuçların algılanan önemi. \\
\hline Hata Olasıllı̆ı & Yanlış bir seçim yapmanın algılanan olasıllığı. \\
\hline
\end{tabular}

Kaynak: Kapferer, J.N. ve Laurent, G. (1985). Consumer Involvement Profiles: A New Practical Approach to Consumer Involvement, Journal of Advertising Research, Vol.25, No.6, ss.50.

İgilenim kavramı memnuniyet, marka bağ|ılığı, marka sadakati, reklam ve bu gibi diğer pek çok pazarlama kavramıyla ilişkilendirilen ve son 50 yıldır tüketici davranışı literatüründe yaygın olarak kullanılan bir kavramdır (Michaelidou ve Dibb, 2008, s.3). Ilgilenim, tüketicilerin satın alma davranışları üzerinde etkili olan nedensel veya motivasyonel değişkenlerden biridir. Bu nedenle tüketicilerin ilgilenim seviyesi, onların satın alma karar sürecinde büyük oranda farklılaşmalarını sağlamaktadır (Kapferer ve Laurent, 1985/1986, s.42).

\subsection{Tüketici IIIgilenimi ve Marka Sadakati Arasındaki İlişkiler}

Tüketici ilgileniminin marka sadakati üzerindeki etkisini ortaya koymaya yönelik araştırmalar incelendiğinde, kullanılan ölçeğe ve baz alınan ürüne göre farklı sonuçlar ortaya çıkmasına rağmen genellikle beklenen etkilerin bulunduğu görülmektedir. Bu çalışmada ise, bulguların tutarlılı̆ını sağlamak açısından sadece CIP ölçeği kullanılarak yapılan ve ilgilenimin sadakat üzerindeki etkisinin irdelendiği kısıtlı sayıdaki araştırmaya yer verilmiştir.

Türkiye'de kot pantolon ürününe yönelik ilgilenimin marka sadakati üzerindeki etkisini ortaya koymaya yönelik olarak yürütülen bir çalışmada CIP ölçeği dört boyutlu olarak ortaya çıkmıştır. Kapferer ve Laurent'in (1985) çalışmasında ortaya çıkan beş boyuttan ilgi ve hedonik değer boyutlarının bu çalışmada birleştiği görülmektedir. Araştırma sonucunda, dört boyutun tamamının marka sadakati üzerinde etkili olduğu saptanmıştır (Çilingir ve Yıldız, 2010). Spor ayakkabı ve tükenmez kalem ürünlerine yönelik ilgilenimin marka sadakati üzerindeki etkisini saptamak amacıyla üniversite öğrencileri üzerinde yürütülen bir çalışmada ise yapılan faktör analizi farklı sonuçları ortaya çıkarmıştır. Örneğin, spor ayakkabıya yönelik ilgilenim soruları dört faktörden oluşurken, tükenmez kalem ilgilenimi için üç faktör ortaya çıkmıştır. Araştırma sonuçları, spor ayakkabı ürününe yönelik ilgilenimin ilgi ve hedonik değer boyutu ile sembolik değer boyutunun marka sadakati üzerinde pozitif etkisini ortaya koyarken; risk önemi ve hata olasılığı boyutlarının marka sadakati üzerinde var olan negatif etkisi istatistiksel olarak anlamsız bulunmuştur. Diğer taraftan tükenmez kalem ilgileniminin sembolik ve hedonik değer boyutu ile risk önemi boyutunun marka sadakati üzerinde pozitif; hata olasılığı boyutunun ise negatif bir etkisi saptanmıştır (Quester ve Lim, 2003). Üniversite öğrencileri üzerinde yürütülen bir başka çalışmada, tüketici ilgileniminin ilgi, hedonik değer ve sembolik değer boyutlarının marka sadakati üzerinde pozitif bir etkisi saptanırken; risk önemi ve hata olasılığı boyutlarının herhangi bir anlamlı etkisi saptanamamıştır (Hanzaee, Khoshpanjeh ve Rahnama, 2011). Yetişkin fitness programı katılımcıları üzerinde yürütülen bir başka çalışmada ise, her ne kadar ilgilenimin sadakat üzerindeki etkisi incelenmemiş olsa da, bu iki değişken arasında pozitif bir korelâsyon bulunmuştur (Park, 1996). Prayag ve Ryan (2012) tarafından yapılan bir araştırmada ise, Mauritius adasındaki otellerde konaklayan ziyaretçilerin bu deneyimlerine yönelik kişisel ilgilenimlerinin sadakatin boyutları olan yeniden ziyaret etme ve başkalarına tavsiye etme üzerinde bir etkisi saptanamamıştır. Havayolu hizmetleri kapsamında yolcuların ilgilenim düzeylerinin sadakat üzerindeki etkisinin incelendiği başka bir çalışmada, hedonik ve sembolik değer boyutlarının tutumsal sadakat üzerinde pozitif ve anlamlı bir etkisi bulunurken, ilgi boyutunun anlamlı bir etkisi saptanamamıştır (Chen, Wang, Cheng ve Kuntjara, 2008). 
Görüldüğü üzere literatürdeki konuyla ilgili çalışmaların sonuçları farklılık göstermektedir. Ayrıca, ilgilenimin sadakat üzerindeki etkisinin CIP ölçeği kullanılarak araştııılığı çalışmalar oldukça az sayıdadır. Gerek literatüre bir katkıda bulunmak, gerekse akıllı telefon ürününe yönelik bu araştırma sayesinde literatürü nispeten zenginleştirmek amacıyla aşağıdaki hipotezler geliştirilmiştir.

H1: Tüketicilerin akıllı telefon ilgilenimlerinin ilgi boyutunun sadakatin tavsiye etme boyutu üzerinde pozitif yönlü ve anlamlı bir etkisi vardır.

H2: Tüketicilerin akıllı telefon ilgilenimlerinin ilgi boyutunun sadakatin müşterisi olma boyutu üzerinde pozitif yönlü ve anlamlı bir etkisi vardır.

H3: Tüketicilerin akıllı telefon ilgilenimlerinin sembolik değer boyutunun sadakatin tavsiye etme boyutu üzerinde pozitif yönlü ve anlamlı bir etkisi vardır.

H4: Tüketicilerin akıllı telefon ilgilenimlerinin sembolik değer boyutunun sadakatin müşterisi olma boyutu üzerinde pozitif yönlü ve anlamlı bir etkisi vardır.

H5: Tüketicilerin akıllı telefon ilgilenimlerinin hata olasılığı boyutunun sadakatin tavsiye etme boyutu üzerinde negatif yönlü ve anlamlı bir etkisi vardır.

H6: Tüketicilerin akıllı telefon ilgilenimlerinin hata olasılığı boyutunun sadakatin müşterisi olma boyutu üzerinde negatif yönlü ve anlamlı bir etkisi vardır.

H7: Tüketicilerin akıllı telefon ilgilenimlerinin risk önemi boyutunun sadakatin tavsiye etme boyutu üzerinde negatif yönlü ve anlamlı bir etkisi vardır.

H8: Tüketicilerin akıllı telefon ilgilenimlerinin risk önemi boyutunun sadakatin müşterisi olma boyutu üzerinde negatif yönlü ve anlamlı bir etkisi vardır.

H9: Tüketicilerin akıllı telefon ilgilenimlerinin hedonik değer boyutunun sadakatin tavsiye etme boyutu üzerinde pozitif yönlü ve anlamlı bir etkisi vardır.

H10: Tüketicilerin akıllı telefon ilgilenimlerinin hedonik değer boyutunun sadakatin müşterisi olma boyutu üzerinde pozitif yönlü ve anlamlı bir etkisi vardır.

\section{YÖNTEM}

Bu bölümde araştırmanın amacı ve modeli, araştırmanın evreni ve örneklem ile anket formunun tasarımı açıklanmaktadır.

\subsection{Araştırmanın Amacı ve Modeli}

Bu araştırmanın amacı, üniversite öğrencilerinin akıllı telefon ürününe yönelik ilgilenimlerinin marka sadakati üzerindeki etkisini ortaya koymaktır. Bu amaca ulaşmak için, tüketici ilgileniminin beş boyutunun marka sadakatinin iki boyutu üzerindeki etkileri incelenmiştir. Bu etkiler Şekil 1'de yer alan araştırmanın teorik modelinde görülmektedir. 


\section{Şekil 1. Araştırmanın Teorik Modeli}

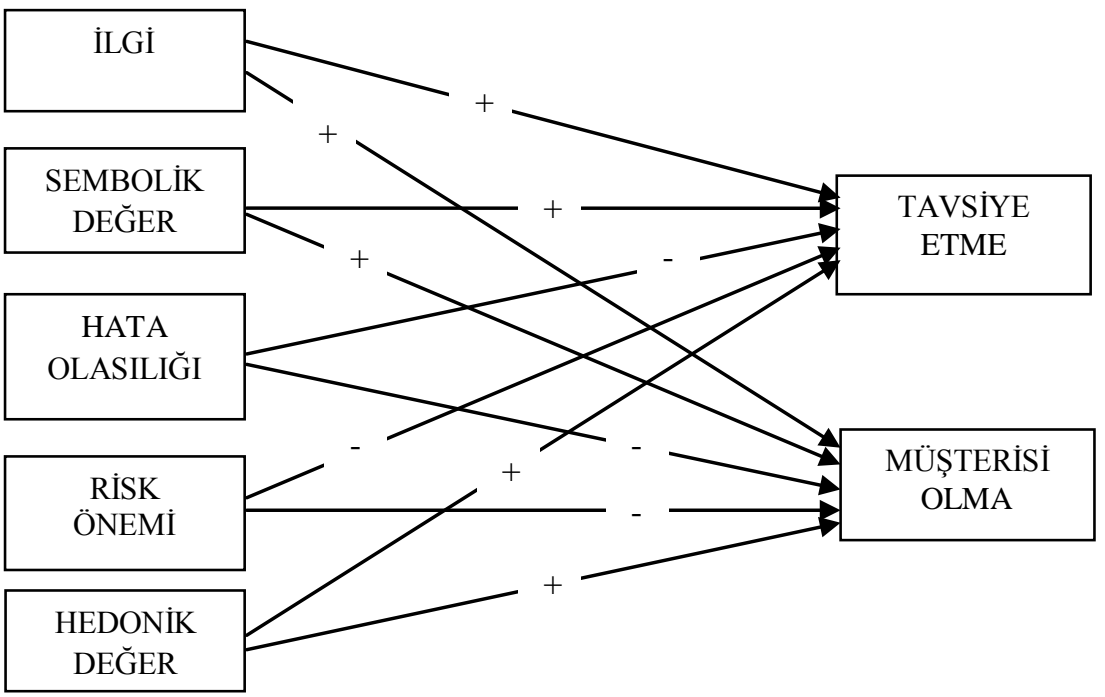

Şekil 1'de gösterilen araştırma modeline göre tüketici ilgileniminin beş boyutundan ilgi, sembolik değer ve hedonik değer değişkenlerinin sadakatin tavsiye etme ve müşterisi olma boyutları üzerinde pozitif; hata olasılığı ve risk önemi değişkenlerinin ise negatif etkileri beklenmektedir.

\subsection{Araştırmanın Evreni ve Örneklem}

Araştırmanın ana kütlesini Balıkesir Üniversitesi Burhaniye Uygulamalı Bilimler Yüksekokulu'nda 2015-2016 güz döneminde öğrenim görmekte olan Bankacılık ve Finans, Turizm İşletmeciliği ve Otelcilik ve Uluslararası Ticaret bölümü öğrencileri oluşturmaktadır. Uygulamanın yapıldığı tarihte bu bölümlerde öğrenim gören devamlı öğrenci sayısı yaklaşık olarak 1000'dir. Araştırma, bu ana kütleden kolayda örnekleme yöntemiyle belirlenen 730 öğrenci üzerinde Kasım-Aralık 2015 tarihleri arasında yüz yüze anket yöntemiyle gerçekleştirilmiştir. Geri dönüs yapılan anket formları içerisinden yanlıs ya da eksik doldurulan, soruların tümünde ya da büyük bir kısmında aynı seçeneğin işaretlendiği ve okunmadan cevaplandığı anlaşılan anket formları analiz kapsamına dâhil edilmemiştir. Uygulama sonucunda, analiz kapsamında kullanılabilecek 665 anket formu ile analizler gerçekleştirilmiştir. Araştırma evreninin öğrenciler olarak seçilmesinin nedeni akıllı telefon pazarında genç tüketicilerin hayli aktif olmasıdır.

\subsection{Anket Formunun Tasarımı}

Araştırmada kullanılan tüketici ilgilenimi soruları Kapferer ve Laurent'in (1985) çalışmasından adapte edilen 16 sorudan oluşmaktadır. Tüketici Illgilenim Profili ölçeğinde ilgi ve risk önemi boyutlarından birer soru ters ifade (reverse) şeklindedir. Bu nedenle verilerin paket programa girilmesinin ardından ilgili soruların cevapları ters çevrilerek doğrusallık sağlanmıştır. Marka sadakatine ilişkin ifadeler ise Zeithaml ve arkadaşlarının (1996) çalışmasında yer alan başkalarına tavsiye etme ve yeniden satın alma niyeti ifadelerinden oluşmaktadır. Bu çalışmada tek boyutlu olarak yer alan sadakat ölçeğini Lam ve arkadaşları (2004) kendi çalışmalarına adapte etmiş ve sadakat ölçeğini iki boyutlu bulmuştur. Bu ölçekte ilk üç soru başkalarına tavsiye etme ve iki soru müşterisi olma (yeniden satın alma) ifadelerinden oluşmaktadır. Bu çalışmada da marka sadakatine yönelik ölçek ifadeleri belirlenirken, Zeithaml ve arkadaşları (1996) ve Lam ve arkadaşları (2004) tarafından yapılan çalışmadan uyarlanan sadakat ölçeğinin tavsiye etme ve müşterisi olma boyutları kullanılmıştır. Ayrıca Zeithaml ve arkadaşlarının (1996) geliştirdiği sadakat ölçeğinde müşterisi olma boyutu iki soruyla ölçüldüğünden ve iki soruyla da ölçüm güvenilirlik bakımından sıkıntılar doğuracağından yazar tarafından tasarlanan bir soru bu boyuta eklenmiştir. 


\section{ARAŞTIRMANIN BULGULARI}

$\mathrm{Bu}$ bölümde araştırma verilerinin analizi sonucunda elde edilen bulgulara yer verilmiştir. Verilerin değerlendirilmesinde ve analizinde SPSS 20.0 (Statistical Package for the Social Science) ve AMOS 18.0 programları kullanılmıştır. Öngörülen modelin ve hipotezlerin test edilebilmesi için, öncelikle elde edilen veriler keşifsel ve doğrulayıcı faktör analizi aracılığıyla güvenilirlik ve geçerlilik testlerinden geçirilmiştir. Ardından, yapısal eşitlik modellemesi kullanılarak araştırma hipotezleri test edilmiştir.

\subsection{Keşifsel ve Doğrulayıcı Faktör Analizi Bulguları}

Tablo 2'de akıllı telefon ürününe ilişkin tüketici ilgilenimi ve marka sadakati alt boyutlarını ortaya koymaya yönelik olarak yapılan keşifsel faktör analizi sonuçları görülmektedir. Faktör analizi işlemi yapılmadan önce verilerin faktör analizine uygun olup olmadığının ve örneklem büyüklüğünün faktör analizi için yeterli olup olmadığının belirlenmesi amacıyla KMO (Kaiser-Meyer-Olkin) değerine bakılması gerekmektedir. KMO testi değerinin 0,6'dan büyük olması önerilmektedir (İslamoğlu ve Alnıaçık, 2014, s.396). Yapılan analiz sonucunda KMO değeri 0,798 olarak hesaplanmıştır. KMO analizinden sonra ise ana kütle içindeki değişkenler arasında bir ilişkinin var olup olmadığını belirlemek amacıyla Bartlett’ın Küresellik Testi sonuçları incelenmiştir. Faktör analizinin uygulanabilmesi için bu testin sonucunun anlamlı çıkması $(p<0,05)$ istenmektedir (İslamoğlu ve Alnıaçık, 2014, s.396). Bu test değerinin anlamlı çıkması ilişkinin varlığını ve bu verinin faktör analizi yapmak için uygun olduğunu göstermektedir (Nakip, 2006, s.428- 429). Bu araştırma özelinde Bartlett'ın Küresellik Testi'nin anlamlılık düzeyi 0,001 olarak hesaplanmıştır. Gerek KMO, gerekse Bartlett’ın Küresellik Testi sonuçları araştırma verilerinin faktör analizi yapmak için uygun olduğunu ve örnek büyüklüğünün bu analiz için yeterli olduğunu göstermektedir. Tablo 2'deki bulgular, hem tüketici ilgilenimi hem de marka sadakati alt boyutlarının beklendiği gibi ayrıştığını ve soruların ilgili faktörlere yüklendiğini göstermektedir. Keşifsel faktör analizi sonucunda açıklanan varyans değeri \%70,657 olarak hesaplanmıştır. Bu değerin sosyal bilimler için en az \%60 olması arzulanmaktadır (Nakip, 2006, s.432). Araştırmada bu kriterin sağlandığı görülmektedir. Ayrıca tüm boyutlara ilişkin faktör yüklerinin kritik eşiğin oldukça üzerinde olduğu görülmektedir $(\geq 0,55)$.

Tablo 2: Akıllı Telefon Ürününe Yönelik Keşifsel Faktör Analizi Sonuçları

\begin{tabular}{|c|c|c|c|c|c|c|c|}
\hline & 1 & 2 & 3 & 4 & 5 & 6 & 7 \\
\hline \multicolumn{8}{|l|}{ İLGi } \\
\hline Bir___ satın almak benim için son derece önemlidir. & 0,867 & & & & & & \\
\hline Bir___ satın almak umrumda bile değildir. & 0,854 & & & & & & \\
\hline Bir___'na gerçekten çok ilgi duyarım. & 0,780 & & & & & & \\
\hline \multicolumn{8}{|l|}{ HATA OLASILIĞI } \\
\hline $\begin{array}{l}\text { Hata yapma ihtimalinden dolayı, bir __ satın aldığımda onun } \\
\text { gerçekten aradığım _ olup olmadığını bilemem. }\end{array}$ & & 0,805 & & & & & \\
\hline $\begin{array}{l}\text { Hata yapma ihtimalinden dolayı, bir __ satın alırken doğru } \\
\text { tercihi yaptığımdan asla tam emin olamam. }\end{array}$ & & 0,756 & & & & & \\
\hline $\begin{array}{l}\text { Hata yapma ihtimalinden dolayı, bir __ satın alırken hangisini } \\
\text { seçmem gerektiği konusunda kararsızık yaşarım. }\end{array}$ & & 0,750 & & & & & \\
\hline $\begin{array}{l}\text { Hata yapma ihtimalinden dolayı, bir __ seçmek oldukça zor bir } \\
\text { iştir. }\end{array}$ & & 0,740 & & & & & \\
\hline \multicolumn{8}{|l|}{ HEDONIK DEĞER } \\
\hline Bir___almak kendime bir hediye vermektir. & & & 0,878 & & & & \\
\hline Kendime bir___ almak benim için bir zevktir. & & & 0,849 & & & & \\
\hline Bir___ 'na sahip olmak beni mutlu eder. & & & 0,680 & & & & \\
\hline \multicolumn{8}{|l|}{ SEMBOLIK DEĞER } \\
\hline Birinin seçtiği ___ onun kim olduğu hakkında ipuçları verir. & & & & 0,888 & & & \\
\hline Seçtiğim bir __ benim kişiliğimi yansıtır. & & & & 0,770 & & & \\
\hline $\begin{array}{l}\text { Birinin seçtiği___na bakarak onun hakkında bir şeyler } \\
\text { söyleyebilirsin. }\end{array}$ & & & & 0,687 & & & \\
\hline
\end{tabular}




\begin{tabular}{|c|c|c|c|c|c|c|c|}
\hline \multicolumn{8}{|l|}{ RiSK ÖNEMI } \\
\hline Yanlış bir ___ satın almak benim için çok rahatsız edicidir. & & & & & 0,847 & & \\
\hline $\begin{array}{l}\text { Bir } \\
\text { değildir. }\end{array}$ & & & & & 0,767 & & \\
\hline $\begin{array}{l}\text { Bir__satın aldıktan sonra kötü bir seçim yaptığımı anlarsam } \\
\text { kendime çok kızarım. }\end{array}$ & & & & & 0,712 & & \\
\hline \multicolumn{8}{|l|}{ MÜŞTERISI OLMA } \\
\hline Aynı___ markasının müşterisi olmayı sürdüreceğim. & & & & & & 0,916 & \\
\hline Her zaman için ilk tercihim bu ___ markası olacaktır. & & & & & & 0,884 & \\
\hline $\begin{array}{l}\text { Gelecek yıllarda da aynı __ markasını kullanmaya devam } \\
\text { edeceğim. }\end{array}$ & & & & & & 0,883 & \\
\hline \multicolumn{8}{|l|}{ TAVSIYE ETME } \\
\hline $\begin{array}{l}\text { Benim önerilerimi isteyen arkadaşlarıma kullandığım _ } \\
\text { markasını tavsiye ederim. }\end{array}$ & & & & & & & 0,824 \\
\hline 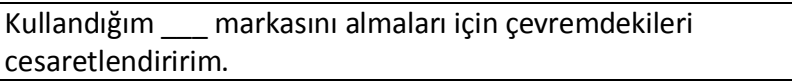 & & & & & & & 0,746 \\
\hline $\begin{array}{l}\text { Çevreme kullandığım __ markası hakkında olumlu şeyler } \\
\text { söylerim. }\end{array}$ & & & & & & & 0,728 \\
\hline ÖZ DEĞER & 3,165 & 2,106 & 1,699 & 1,368 & 1,005 & 4,773 & 1,428 \\
\hline AÇIKLANAN VARYANS (\%) & 14,386 & 9,575 & 7,724 & 6,220 & 4,566 & 21,696 & 6,491 \\
\hline TOPLAM AÇIKLANAN VARYANS (\%) & \multicolumn{7}{|c|}{70,657} \\
\hline
\end{tabular}

Araştırmada kullanılan ölçeklerin boyutları Keşifsel Faktör Analizi ile belirlenmiştir. Ancak, araştırma soruları genel olarak yabancı dilde yazılmış kaynaklardan alındığı için, Türkçe uygulamasında ölçeğin doğrulanması gerekmektedir. Bu nedenle, Doğrulayıcı Faktör Analizi'nin (DFA) yapılması gerekli görülmüştür. AMOS 18.0 paket programıyla gerçekleştirilen analiz sonucunda araştırma sorularının ilgili faktörlere yüksek faktör yükleri ile yüklendiği görülmüştür (0,53-0,96 arasında). Uyum iyiliği indeksleri incelendiğinde $\mathrm{X}^{2}$ / sd değeri 2,512 olarak bulunmuştur. Bu değer, veri uyumunun iyi olduğunu göstermektedir. Ayrıca Tablo 3'te görüldüğü gibi hesaplanan SRMR $(0,0485)$, AGFI $(0,917)$, ve RMSEA değerleri $(0,048)$ faktör yapısının iyi uyumuna işaret etmekte, CFI $(0,952)$, NFI $(0,923)$ ve GFI $(0,938)$ değerleri ise kabul edilebilir uyum göstermektedir. Bu sonuçlar faktör yapısının genel olarak iyi uyum gösterdiği ve doğrulandığı şeklinde yorumlanabilir.

Tablo 3. DFA Uyum İyiliği Indeksleri

\begin{tabular}{|c|c|c|c|}
\hline $\begin{array}{c}\text { Uyum } \\
\text { Ölçüleri }\end{array}$ & $\begin{array}{c}\text { İyi } \\
\text { Uyum }\end{array}$ & Kabul Edilebilir Uyum & $\begin{array}{c}\text { Araştırmada } \\
\text { Ortaya Çıkan } \\
\text { Değer }\end{array}$ \\
\hline SRMR & $0 \leq \mathrm{SRMR} \leq 0,05$ & $0,05 \leq \mathrm{SRMR} \leq 0,10$ & 0,0485 \\
\hline GFI & $0,95 \leq \mathrm{GFI} \leq 1,00$ & $0,90 \leq \mathrm{GFI}<0,95$ & 0,938 \\
\hline AGFI & $0,90 \leq \mathrm{AGFI} \leq 1,00$ & $0,85 \leq \mathrm{AGFI}<0,90$ & 0,917 \\
\hline NFI & $0,95 \leq \mathrm{NFI} \leq 1,00$ & $0,90 \leq \mathrm{NFI}<0,95$ & 0,923 \\
\hline CFI & $0,97 \leq \mathrm{CFI} \leq 1,00$ & $0,95 \leq \mathrm{CFI}<0,97$ & 0,952 \\
\hline RMSEA & $0 \leq \mathrm{RMSEA} \leq 0,05$ & $0,05<\mathrm{RMSEA} \leq 0,08$ & 0,048 \\
\hline
\end{tabular}

Kaynak: Bayram, N. (2010). Yapısal Eşitlik Modellemesine Giriş: AMOS Uygulamaları. (1). Bursa. Ezgi Kitabevi. 


\subsection{Güvenilirlik Analizi Bulguları}

Araştırma sorularının güvenilirliğini ölçmek amacıyla Likert ölçeği ile ölçüm gerçekleştirilen çalışmalarda yaygın bir biçimde kullanılan Cronbach'ın Alfa Katsayısı kullanılmıştır. Tablo 4'te görüldüğü gibi tüm boyutların güvenilirlik katsayısı kritik değer olarak kabul edilen 0,70'in üzerinde hesaplanmıştır. Tüm soruların birlikte değerlendirildiği analiz sonucunda, Cronbach'ın Alfa Katsayısı 0,779 olarak hesaplanmıştır. Bu sonuçlar araştırma ölçeklerinin güvenilir olduğunu göstermektedir (Nakip, 2006, s.145).

Tablo 4: Güvenilirlik Analizi Bulguları

\begin{tabular}{|l|c|c|}
\hline Boyutlar / Ölçekler & $\begin{array}{c}\text { Madde } \\
\text { Sayısı }\end{array}$ & $\begin{array}{c}\text { Cronbach } \boldsymbol{\alpha} \\
\text { Katsayısı }\end{array}$ \\
\hline İlgi & 3 & 0,857 \\
\hline Sembolik Değer & 3 & 0,712 \\
\hline Hata Olasılığı & 4 & 0,776 \\
\hline Hedonik Değer & 3 & 0,800 \\
\hline Risk Önemi & 3 & 0,706 \\
\hline Tavsiye Etme & 3 & 0,756 \\
\hline Müşterisi Olma & 3 & 0,917 \\
\hline
\end{tabular}

\subsection{Araştırmanın Tanımlayıcı İstatistikleri}

Araştırmaya katılan cevaplayıcıların cinsiyetleri incelendiğinde \%52,8'inin kadın (n=351); \%47,2'sinin ise erkek ( $n=314)$ öğrencilerden oluştuğu görülmektedir. Katılımcıların yaşlarının aritmetik ortalaması 20,33 iken hane halkı toplam gelirlerinin ortalaması 1953,69 olarak hesaplanmıştır. Tablo 5'te araştırmanın ana değişkenlerine ilişkin istatistikler yer almaktadır.

Tablo 5: Araştırmanın Ana Değişkenlerine iliş̧kin İstatistikler

\begin{tabular}{|l|c|c|c|c|c|c|c|}
\hline & ILG & SED & HOL & RÖN & HED & TAV & MÜŞ \\
\hline Aritmetik Ortalama & 3,88 & 2,75 & 3,27 & 3,94 & 3,66 & 3,56 & 3,25 \\
\hline Standart Sapma & 0,97 & 1,03 & 0,94 & 0,93 & 1,05 & 0,92 & 1.12 \\
\hline
\end{tabular}

íLG: İlgi; SED: Sembolik Değer; HOL: Hata Olasılığı; RÖN: Risk Önemi; HED: Hedonik Değer; TAV: Tavsiye Etme; Müş: Müşterisi Olma

Tablo 5'te yer alan bulgulara göre, Tüketici İlgilenim Profili ölçeğinin boyutlarından biri olan ilgi boyutu için hesaplanan genel ortalama 3,88 olarak bulunmuştur. Bu sonuç ankete katılan öğrencilerin akıllı telefon ürününe yönelik ilgilerinin ortalamanın oldukça üzerinde olduğunu göstermektedir. Ölçeğin sembolik değer boyutu için hesaplanan ortalama 2,75 olarak bulunmuştur. Bu bulgu teknolojik bir ürün olan akıllı telefon ürününün genel cevaplayıcılar için ortalamanın altında bir sembolik değer ifade ettiğini göstermektedir. Dolayısıyla, cevaplayıcıların kullandıkları akıllı telefonun kendi kişiliklerini yansıttığına olan inançları ortalamanın altında kalmaktadır. Tüketici ilgilenim profili ölçeğinin hata olasılığı boyutu için hesaplanan genel aritmetik ortalama 3,27, risk önemi boyutu için ise 3,94 olarak hesaplanmıştır. Bu sonuçlar cevaplayıcıların akıllı telefon ürününe yönelik hatalı bir seçim yapma ihtimalinin ortalamanın üzerinde bir değerde algılanmasının yanı sıra, akıllı telefonu yüksek riskli bir ürün olarak gördüklerinin de bir göstergesidir. Hedonik değer boyutu için hesaplanan genel ortalama 3,66 olarak bulunmuştur. Bu bulgu ankete katılan öğrencilerin akıllı telefon ürününde ortalamanın üzerinde bir hedonik değer algıladığını göstermektedir.

Marka Sadakati değişkeni anket formunda 6 soruyla ölçülmüştür. Sadakat ölçeğinin tavsiye etme ve müşterisi olma boyutları için hesaplanan genel aritmetik ortalama sırasıyla 3,56 ve 3,25 olarak bulunmuştur. Bu sonuç 
ankete katılan öğrencilerin kullandıkları akıllı telefon markasına yönelik sadakatlerinin ortalamanın üzerinde olduğunu göstermektedir.

\subsection{Hipotezlerin Testi}

Araştırma modelinde yer alan hipotezlerin yapısal eşitlik modeli ile test edilmesi ile ortaya çıkan sonuçlar Şekil 2'de görülmektedir.

Şekil 2: Araştırma Modelinin Testi

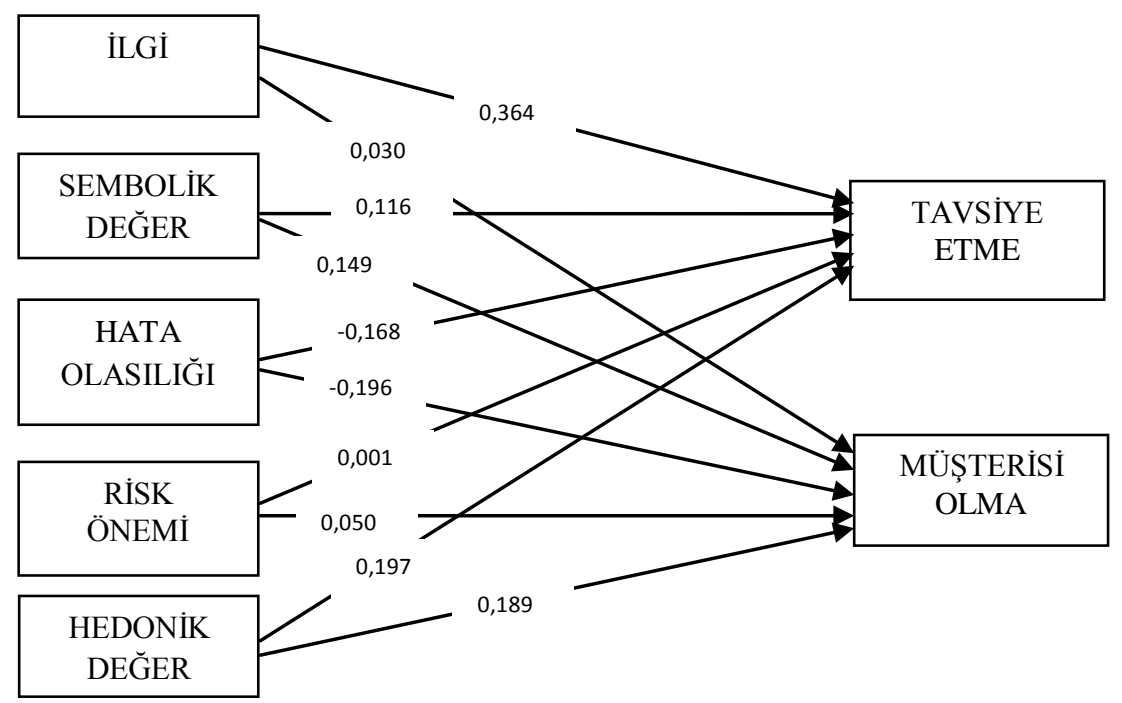

Tablo 6'da araştırma hipotezlerinin yapısal eşitlik modeli ile test edilmesi ile ortaya çıkan bulgular yer almaktadır.

Tablo 6: Yapısal Eşitlik Modeli ile Hipotezlerin Test Sonuçları

\begin{tabular}{|c|c|c|c|c|c|}
\hline Hipotezler & $\begin{array}{l}\text { Bağımsız } \\
\text { Değişken }\end{array}$ & $\begin{array}{l}\text { Bağımlı } \\
\text { Değişken }\end{array}$ & $\begin{array}{c}\text { Standardize } \\
6\end{array}$ & p & Sonuçlar \\
\hline H1 & ilgi & Tavsiye Etme & 0,364 & 0,001 & Desteklendi \\
\hline $\mathrm{H} 2$ & İlgi & $\begin{array}{c}\text { Müşterisi } \\
\text { Olma }\end{array}$ & 0,030 & 0,562 & Desteklenmedi \\
\hline H3 & Sembolik Değer & Tavsiye Etme & 0,116 & 0,012 & Desteklendi \\
\hline H4 & Sembolik Değer & $\begin{array}{l}\text { Müşterisi } \\
\text { Olma }\end{array}$ & 0,149 & 0,001 & Desteklendi \\
\hline H5 & Hata Olasılı̆̆ı & Tavsiye Etme & $-0,168$ & 0,001 & Desteklendi \\
\hline H6 & Hata Olasılı̆̆ı & $\begin{array}{l}\text { Müşterisi } \\
\text { Olma }\end{array}$ & $-0,196$ & 0,001 & Desteklendi \\
\hline H7 & Risk Önemi & Tavsiye Etme & 0,001 & 0,978 & Desteklenmedi \\
\hline H8 & Risk Önemi & $\begin{array}{l}\text { Müşterisi } \\
\text { Olma }\end{array}$ & 0,050 & 0,346 & Desteklenmedi \\
\hline H9 & Hedonik Değer & Tavsiye Etme & 0,197 & 0,001 & Desteklendi \\
\hline H10 & Hedonik Değer & $\begin{array}{l}\text { Müşterisi } \\
\text { Olma }\end{array}$ & 0,189 & 0,001 & Desteklendi \\
\hline
\end{tabular}


Tablo $6^{\prime}$ da yer alan araştırma hipotezlerinin test sonuçları incelendiğinde tüketici ilgileniminin ilgi boyutunun sadakatin tavsiye etme boyutu üzerinde güçlü bir etkisi görülürken $(B=0,364 ; p=0,001)$; müşterisi olma boyutu üzerinde anlamlı bir etkisi saptanamamıştır. Bu sonuçlara göre, $\mathrm{H} 1$ hipotezi desteklenirken $\mathrm{H} 2$ hipotezi desteklenmemiştir. Illgilenimin sembolik değer boyutunun sadakatin hem tavsiye etme $(\beta=0,116 ; p=0,012)$ hem de müşterisi olma $(B=0,149 ; p=0,001)$ boyutları üzerinde anlamlı bir etkisi tespit edilmiştir. Buna göre H3 ve H4 desteklenmiştir. Hata olasılığı boyutunun da beklendiği gibi tavsiye etme $(B=-0,168 ; p=0,001)$ ve müşterisi olma $(B=-0,196 ; p=0,001)$ boyutları üzerinde negatif bir etkisi saptanmıştır. Bu bulgulara göre $\mathrm{H} 5$ ve $\mathrm{H} 6$ hipotezleri desteklenmiştir. Tüketici ilgileniminin risk önemi boyutunun tavsiye etme ve müşterisi olma boyutları üzerinde anlamlı bir etkisi saptanamamışır. Buna göre $\mathrm{H7}$ ve $\mathrm{H} 8$ hipotezleri desteklenmemiştir. Ilgilenimin son boyutu olan hedonik değerin ise sadakatin hem tavsiye etme $(b=0,197 ; p=0,001)$ hem de müşterisi olma $(b=0,189$; $\mathrm{p}=0,001$ ) boyutları üzerinde pozitif ve anlamlı bir etkisi saptanmıştır. Bu bulgulara göre $\mathrm{H} 9$ ve $\mathrm{H} 10$ hipotezleri desteklenmiştir.

\section{SONUÇ VE ÖNERILER}

Bu araştırma üniversite öğrencilerinin akıllı telefon ilgilenimlerinin marka sadakati üzerindeki olası etkisini tespit etmek amacıyla gerçekleştirilmiştir. Araştırma bulguları bu etkiyi desteklemektedir. Bulgular, tüketici ilgileniminin sembolik değer ve hedonik değer boyutlarının marka sadakatinin hem tavsiye etme hem de müşterisi olma boyutları üzerinde pozitif ve anlamlı etkilerini ortaya koymaktadır. Bu sonuç, tüketicilerin kullandıkları akıllı telefonu kendi kişiliklerini yansıtan bir ürün olarak algılamaları halinde markaya yönelik sadakatlerinin artacağını göstermektedir. Benzer şekilde, tüketicilerin kullandıkları akılı telefon ürününden haz almaları, bu ürünü satın almaktan hoşlanmaları ve mutlu olmaları durumunda da sadakat düzeylerinin yükseleceği söylenebilir. Bu sonuçlara göre, akıllı telefon sektöründe faaliyet gösteren firmalara tüketicilerin kişiliğini yansıtan ve onların haz almalarını sağlayacak ürünlere ağırlık vermeleri ve pazarlama iletişimi çabalarında bu özellikleri ön plana çıkarmaları tavsiyesinde bulunulabilir.

Araştırma bulguları tüketici ilgileniminin hata olasılığı boyutunun, sadakatin tavsiye etme ve müşterisi olma boyutları üzerinde negatif bir etkisi olduğunu ortaya koymaktadır. Bu sonuç, tüketicilerin akıllı telefonu satın alırken teknolojik yönü ve yüksek fiyatı gibi nedenlerle hata yapma ihtimalini yüksek olarak algılamaları halinde sadakat düzeylerinin azalacağı şeklinde yorumlanabilir. Bu nedenle, birçok marka ve model arasından seçim yapmak durumunda kalan tüketicinin akıllı telefon ürününde hatalı seçim yapmaktan duydukları kaygıyı en aza indirgemek için işletmelerin fiyat, garanti ve ürün özelliklerinin üstünde durmaları gerektiği söylenebilir.

Araştırmanın diğer bir önemli sonucu ise, tüketici ilgileniminin ilgi boyutunun sadakatin tavsiye etme boyutu üzerindeki pozitif etkisidir. Bu sonuç, akıllı telefona ilgi duyan tüketicilerin kullandıkları markayı başkalarına tavsiye edeceklerini göstermektedir. Herhangi bir ürüne özel bir ilgi duyan kişilerin, bu bilgilerini başkalarıyla paylaşmasının ya da akıllı telefon gibi riskli bir üründe tüketicilerin bu ürüne ilgi duyan kişilerden tavsiye almasının beklenen bir sonuç olduğu söylenebilir. Bu noktada firmalara, marka sadakati geliştirebilmeleri için tüketiciler üzerinde ilgi uyandıracak özelliklere sahip ürünler geliştirmeleri önerisinde bulunulabilir.

Araştırmanın diğer sonuçları, ilgi boyutunun müşterisi olma; risk önemi boyutunun ise hem tavsiye etme hem de müşterisi olma boyutları üzerinde beklenen etkisinin saptanamamış olmasıdır. Buna göre, akıllı telefon ürününe ilgi duyan ya da önem veren bir tüketicinin kullandığı markayı satın almaya devam edeceği yönündeki araştırma hipotezi reddedilmiştir. Diğer taraftan, akıllı telefon ürünü satın alımında yanlış bir karar verme riskinin önemli olarak algılanmasının da marka sadakati üzerinde anlamlı bir etkisi bulunamamıştır.

Bu araştırmada tüketici ilgilenimi, Tüketici İlgilenim Profili ölçeği ile analiz edilmiştir. Zaichkowsky’nin (1985) Kişisel ilgilenim Envanteri (Personal Involvement Inventory-PII) veya diğer ürün ilgilenimi ölçekleri kullanılarak aynı ürün üzerinde benzer bir çalışma yapılarak modelin geçerliliği sınanabilir. Yine bu araştırma, sembolik değeri nispeten yüksek olan akıllı telefon ürünü temelinde gerçekleştirilmiştir. Sonraki çalışmalarda farklı ürün kategorilerinden ürünler seçilerek tüketici ilgileniminin marka sadakati üzerindeki etkisi incelenebilir. Araştırmada zaman ve maliyet kısııından dolayı kolayda örnekleme yöntemi kullanılmış ve sadece Balıkesir Üniversitesi Burhaniye Uygulamalı Bilimler Yüksekokulu öğrencileri örnekleme dâhil edilmiştir. Araştırmada bu kitlenin kullanılmasının nedeni, üniversite öğrencilerinin akıllı telefon ürününe yönelik bilinç ve ilgilenim 
düzeyinin diğer kitlelerden daha yüksek olacağı beklentisidir. Sonraki çalışmalarda diğer kitlelere de hitap eden farklı ürünler seçilip, modelin geçerliliği sınanabilir.

\section{KAYNAKÇA}

Aeker, D. (1991). MANaging Brand Equity, The Free Press, NeW York.

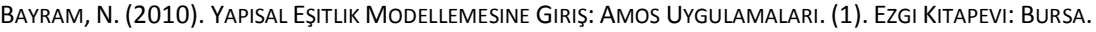

Bloch, P.H. (1986). The Product Enthusiasm: Implications for Marketing Strategy. Journal of Consumer MaRketing, 3(3), $51-62$.

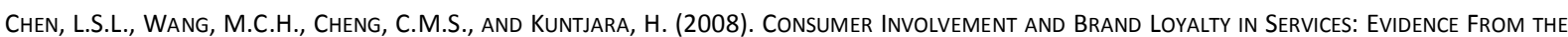
COMMERCIAL AIRLINE INDUSTRY IN TAIWAN. INTERNATIONAL JOURNAL OF SERVICES AND STANDARDS, 4(4), 437-452.

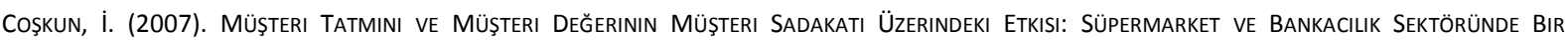
ARAŞTIRMA. YÜKSEK LISANS TEZI. ESKIŞEHIR OSMANGAZI ÜNIVERSITESI SOSYAL BILIMLER ENSTITÜSÜ, ESKIŞEHIR.

ÇAKIR, V. (2007). TÜKETICI İlgILENIMINI ÖLÇMEK. SelÇUK ÜNIVERSITESI İLETIŞIM FAKÜLTESI AKADEMIK DeRGISI, 4(4), $163-180$.

ÇIFTYILDIZ, S.S. VE SÜtÜTEMIZ, N. (2007). TÜKETICI İLGISININ MARKA BAĞLILIĞINA ETKISI. KOCAELI ÜNIVERSITESI SOSYAL BILIMLER ENSTITÜSÜ DERGISI, 13(1), 3755.

ÇILINGIR, Z. VE YILDIZ, S. (2010). TÜKETICILERIN ÜRÜNLERE OlAN İLGILENIMININ MARKA SADAKATI ÜZERINDEKI ETKISI: SEMBOLIK NITELIKTEKI BIR ÜRÜN GRUBU İ̧̧IN İSTANBul İlı PILOT ÇALIŞMASI. ZONGULDAK KARAeLmas ÜNIVERSITESI SOSYAL BILIMLER DERGISI, 6(11), 79-10.

DAy, G.S. (1970). Buyer Attitudes And Brand Choice Behavior. Free Press, NeW York, NY.

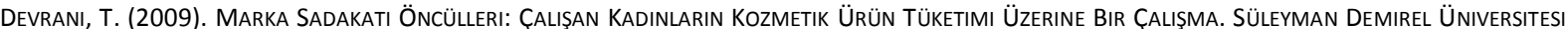
ÍKTISADI VE İDARI BILIMLER FAKÜLTESI DERGISI, 14(3), 407-421.

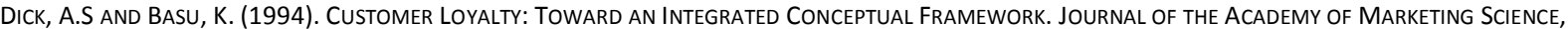
22(2), 99-113.

Dölarslan, E.Ş. (2015). Tüketicilerin Ürün İlgilenim ve Bilgi Düzeyinin Marka Sadakatine Etkisinin Fikir Liderliği Kapsamında Değerlendirilmesi. Pazarlama ve Pazarlama Araştırmaları Dergisi, 15, 23-48.

Eren, S. ve Erge, A. (2012). Marka Güveni, Marka Memnuniyeti ve Müşteri Değerinin Tüketicilerin Marka Sadakati Üzerine Etkisi. Journal of Yaşar University, 26(7), 4455-4482.

Fırat, A. ve Azmak, E. (2007). Satın Alma Karar Sürecinde Beyaz Eşya Kullanıcılarının Marka Bağlılığı. Karamanoğlu Mehmetbey Üniversitesi iiBF Dergisi, 2(3), 251-264.

Flint, D.J., Blocker, C.P., and Boutin, P.J. (2011). Customer Value Anticipation, Customer Satisfaction and Loyalty: An Empirical Examination. Industrial Marketing Management, 40(2), 219-230.

Gounaris, S. and Stathakopoulos, V. (2004). Antecedents and Consequences of Brand Loyalty: An Empirical Study. Brand Management, 11(4), 283-306.

Hanzaee, K.H., Khoshpanjeh, M., and Rahnama, A. (2011). Evaluation of the Effects of Product Involvement Facets on Brand Loyalty. African Journal of Business Management, 5(16), 6964-6971.

İslamoğlu, A.H. ve Alnıaçık, Ü. (2014). Sosyal Bilimlerde Araştırma Yöntemleri. (4). Beta Yayın Dağıtım: İstanbul.

Kandemir, D., Atakan, S.S. ve Demirci, C. (2013). İlgilenim Kavramı ve Türkçe İlgilenim Ölçeklerinin Değerlendirilmesi: Tüketici İlgilenimi, Sürekli İlgilenim ve Satın Alma Kararı İlgilenimi. İktisat İşletme ve Finans, 28(330), 21-48.

Kapferer, J.N and Laurent, G. (1985/1986). Consumer Involvement Profiles: A New Practical Approach to Consumer Involvement. Journal of Advertising Research, 25(6), 48-56.

Kapferer, J.N. and Laurent, G. (1985). Measuring Consumer Involvement Profiles, Journal of Marketing Research, 22, 41-53.

Krugman, H.E. (1965). The Impact of Television Advertising: Learning Without Involvement. Public Opinion Quarterly, 29(3), 349-356.

Lam, S.Y., Shankar, V., Erramilli, M.K., and Murthy, B. (2004). Customer Value, Satisfaction, Loyalty, and Switching Costs: An Illustration From a Business-to-Business Service Context. Journal of the Academy of Marketing Science, 32, $293-311$.

Martin, C.L. (1998). Relationship Marketing: A High-Involvement Product Attribute Approach. Journal of Product \& Brand Management, 7(1), 6-26.

Michaelidou, N. and Dibb, S. (2008). Consumer Involvement: A New Perspective. Marketing Review, 8(1), 1-28,

Mittal, B. (1995). A Comparative Analysis of Four Scales of Consumer Involvement. Psychology \& Marketing, 12(7), $663-682$. 
Nakip, M. (2006). Pazarlama Araştırmaları Teknikler ve SPSS Destekli Uygulamalar. Ankara: Seçkin Yayıncılık.

Odabaşı, Y. ve Barış, G. (2002). Tüketici Davranışı, MediaCat Kitapları, Kapital Medya Hizmetleri A.Ş., İstanbul.

Oliver, R.L. (1999). Whence Customer Loyalty. Journal of Marketing, Special Issue, 63, 33-44.

Öztürk, P. (2006). Rekabet Gücü Olarak Marka Faktörü, Marka Oluşturma Stratejileri ve Koruma Sistemleri. İktisat, İşletme ve Finans, 21(244), 66-85.

Park, S-H. (1996). Relationships Between Involvement and Attitudinal Loyalty Constructs in Adult Fitness Programs. Journal of Leisure Research, 28(4), 233-250.

Prayag, G. and Ryan, C. (2012). Antecedents of Tourists' Loyalty to Mauritius: The Role and Influence of Destination Image, Place Attachment, Personal Involvement, and Satisfaction. Journal of Travel Research, 51(3), 342-356.

Prebensen, N.K., Woo, E., Chen, J.S., and Uysal, M. (2012). Motivation and Involvement As Antecedents of the Perceived Value of the Destination Experience. Journal of Travel Research, 52(2), 253-264.

Quester, P. and Lim, A.L. (2003). Product Involvement/Brand Loyalty: Is There a Link?. Journal of Product \& Brand Management, 12(1), 2238 .

Sherif, M. and Sargent, S. (1947). Ego-Involvement and The Mass Media. Journal of Social Issues, 3, 8-16.

Tokmak, G. (2014). Marka Sadakatini Etkileyen Faktörler ve Markaya Bağlılık Noktaları: Bülent Ecevit Üniversitesi i.i.B.F. Öğrencileri Üzerine Bir Uygulama. Yüksek Lisans Tezi. Bülent Ecevit Üniversitesi Sosyal Bilimler Enstitüsü. Zonguldak.

Warrington, P. and Shim, S. (2000). An Empirical Investigation of the Relationship Between Product Involvement and Brand Commitment. Psychology\&Marketing, 17, 761-782.

Yılmaz, V. (2005). Tüketici Memnuniyeti ve İhtiyaçlarının Marka Sadakatine Etkisi: Sigara Markasına Uygulanması. Anadolu Üniversitesi Sosyal Bilimler Dergisi, 5(1), 257-271.

Zaichkowsky, J.L. (1985). Measuring The Involvement Construct. Journal of Consumer Research, 12, 341-352.

Zaichkowsky, J.L. (1986). Conceptualizing Involvement. Journal of Advertising, 15(2), 4-14.

Zeithaml, V.A., Berry, L.L., and Parasuraman, A. (1996). The Behavioral Consequences of Service Quality. Journal of Marketing, 60(2), 31-46. 